\title{
Logo rebranding: Indonesian tax authority public relations strategy in forming organizational culture images
}

\author{
Febri Noviardi \\ febri.noviardi@student.uns.ac.id \\ Magister of Communication Science, Faculty of Social and Political Sciences, \\ Sebelas Maret University, Surakarta, Indonesia
}

Andre Noevi Rahmanto

andreyuda@gmail.com

Department of Communication Science, Faculty of Social and Political Sciences,

Sebelas Maret University, Surakarta, Indonesia

\author{
Yulius Slamet \\ yuliusslamet48@gmail.com \\ Department of Sociology, Faculty of Social and Political Sciences, \\ Sebelas Maret University, Surakarta, Indonesia
}

Article History: Received 2020-01-13, Revised 2020-07-14, Published 2020-07-30

\begin{abstract}
This paper explains how the process of rebranding the logo of the Directorate General of Taxes (DGT) of the Republic of Indonesia carried out by DGT public relations in shaping the image by displaying the cultural values of the Ministry of Finance. This is motivated by the lack of a comprehensive explanation of the process of rebranding the logo in previous studies. At DGT, logo rebranding is carried out because of the low level of the public's trust in the DGT. Therefore, one of the strategies of the DGT public relations is the formation of an institutional image. This study uses a research method with a qualitative approach with data collection conducted by interviewing selected informants using purposive sampling techniques and source triangulation as a technique in testing the validity of the data. The results are analyzed using the Assessment, Communication and Analysis, Design, and Action planning model. The rebranding process was 1) describing the problem, 2) using all channels communication and objectives in delivering a new logo, 3) using professional consultants in planning that consist of research, strategy development, and implementation, 4) as well as carrying out plans, setting rules, and supervising all activities in the DGT's rebranding process.
\end{abstract}


TulisaninimenjelaskanbagaimanaprosesrebrandinglogoDirektoratJenderalPajak(DJP) RI yang dilakukan oleh Humas DJP dalam membentuk citra dengan menampilkan nilainilai budaya organisasi Kemenkeu. Hal ini dilatarbelakangi oleh kurangnya penjelasan yang komprehensif terhadap proses rebranding logo pada studi-studi sebelumnya. Pada $D J P$, rebranding logo dilakukan karena rendahnya tingkat kepercayaan masyarakat terhadap DJP. Oleh karena itu, salah satu strategi Public Relations (PR) adalah dengan pembentukan citra institusi. Penelitian ini menggunakan metode penelitian dengan pendekatan kualitatif dengan pengumpulan data dilakukan dengan cara wawancara kepada informan terpilih menggunakan teknik purposive sampling dan triangulasi sumber sebagai teknik dalam uji keabsahan datanya. Hasilnya dianalisis menggunakan model perencanaan Assessment, Communication and Analysis, Design, dan Action. Proses rebranding yang dilakukan yaitu 1) menggambarkan masalah, 2) menggunakan semua saluran komunikasi dan tujuan dalam memberikan logo baru, 3) menggunakan konsultan profesional dalam perencanaan yang terdiri dari penelitian, pengembangan strategi, dan implementasi, 4) serta melaksanakan perencanaan, menetapkan aturan, dan melakukan pengawasan terhadap seluruh kegiatan pada proses rebranding Ditjen Pajak RI.

Keywords: Corporate Image, Organizational Culture, Public Relations, Rebranding, Tax.

\section{INTRODUCTION}

Organizations nowadays increasingly use rebranding to increase brand relevance and increase operational efficiency (Melewar et al., 2012; Sonenshein, 2010; Vallaster \& Lindgreen, 2011). According to Muzellec \& Lambkin (2006), rebranding is creating a new name, term, symbol, design, or combination of all of them for one brand that cannot be denied to create a (new) differentiation in the mind of the stakeholders. Name and logo are eventually two of some elements in Corporate Visual Identity (CVI) (Melewar \& Saunders, 1998; Van den Bosch et al., 2005). The existence of any change in CVI's elements has an impact on identity and image (Bolhuis et al., 2015). An image is a number of beliefs, ideas, and impressions held by someone against the identity of an object (Kotler \& Keller, 2009; Sutojo, 2004). From these explanations, it can be concluded that the rebranding carried out including rebranding the logo is an important thing to do in forming a better image. In the field of rebranding, which is an emerging area of research, the literature consists largely of descriptive case studies that are scattered across diverse contexts. These studies take divergent theoretical perspectives that often inform only aspects of rebranding, leaving researchers and managers without a comprehensive understanding of the corporate rebranding process (Miller et al., 2014).

Speaking of rebranding, one of the organizations that have done this is the DGT. DGT is the Indonesian tax authority whose role is very important for the country. Organization for Economic Co-operation and Development (OECD) clarifies that the average of a great income in a country was obtained from tax (OECD, 2019). In the context of Indonesia, there are more than $70 \%$ of the National Budget for Indonesia (APBN) regulated and executed by the Directorate General of Taxes (DGT) as a tax authority. The target of income decided by Indonesia's government in 2019 has reached 1,577 trillion, and it has increased over the years (Indonesia Ministry of Finance, 2019a). However, as released by detik.com, Yustinus Prastowo; a Director Center For Indonesia's Taxation Analysis states that Indonesia's tax compliance is still under concern. This evidence proved by the tax coverage ration in the amount of $72 \%$, and with the low ratio at $0,1 \%$ of increase or between $11 \%-125$ in 20042014 (Detik Finance, 2018). This statement is supported by figure 1 ; that is data from OECD which indicates that Indonesia has a 
low grade of tax ratio than other Asia Pacific countries (OECD, 2019).

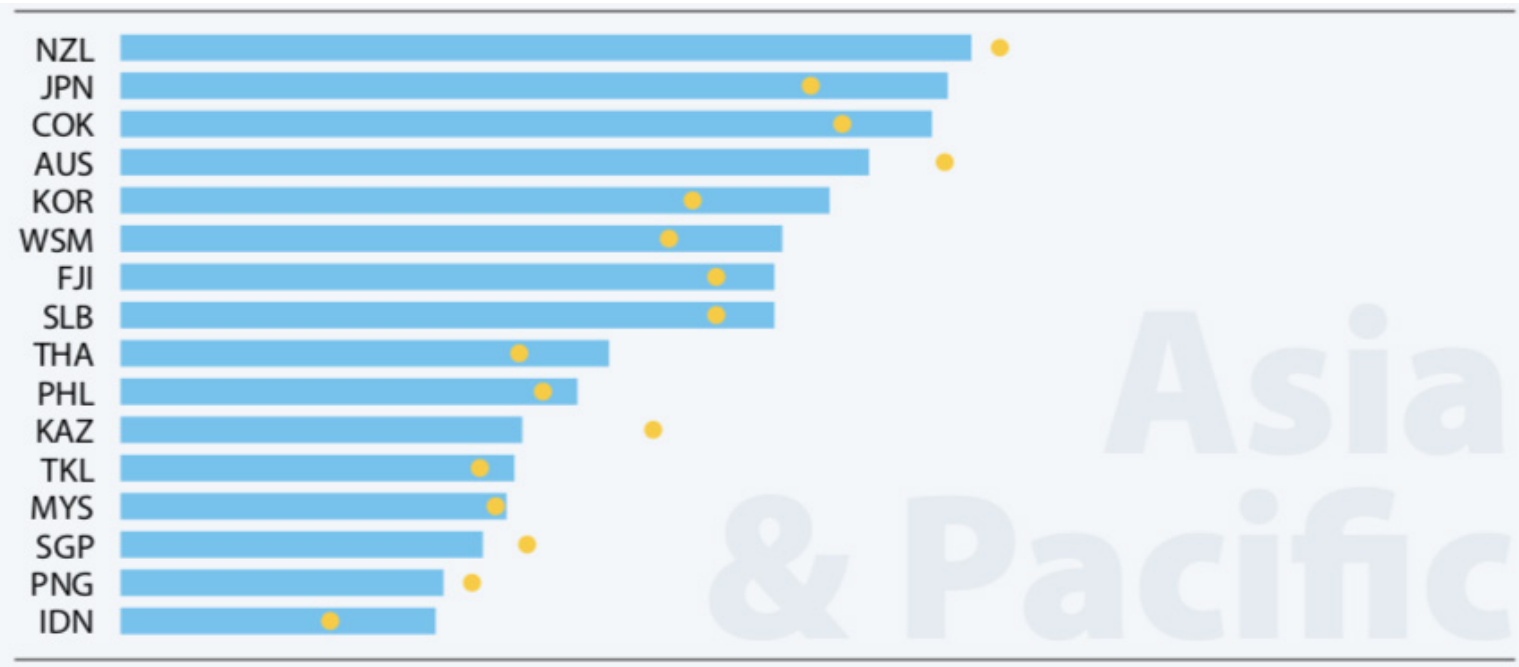

Figure 1: Tax Ratio in the Asia Pacific (Source: OECD)

According to the theory of the slippery slope model, the level of public trust in tax authority has monitored in affecting a level of tax compliance (Kirchler at al., 2008). The data of OECD in Figure 2 implies that a country with a low level of income has an average of low trust (OECD, 2019). Torgler (2007) emphasizes that the public's trust as a person who pays for a tax to the government is a kind of primary relationship. This statement is relevant to research by Ratmono \& Cahyonowati (2016), that trust in tax authority indeed determines tax compliance for an individual than tax inspection and penalty. For Kim (2010), the tendency on the deficiency of the public's trust in government is a global phenomenon, because constructing the public's trust is a complicated treatment.

Several studies have proven that image (impression) has a positive effect on the public's trust (Kaur \& Soch, 2018; Lin \& Lu, 2010; Richard \& Zhang, 2012; Wu, 2014). According toRuslan(1999), oneoftheactivities carried out by Public Relations (HUMAS) is building up an identity and image. As an excellent Public Relations, it is supposed to create a positive identity and image on the public's viewpoint. In the context of Public Relations, 'public' is divided into two genres, namely: internal and external public (Fajri, 2017). On the other hand, the internal and external image in an organization formed by the organization's culture (Obasan, 2012). For Kilman et al. (Lund, 2003), a culture defined as a philosophy, ideology, value, belief, expectation, attitude, and norm that engage the organization. Thus, the image of an organization is closely related to culture in the organization.

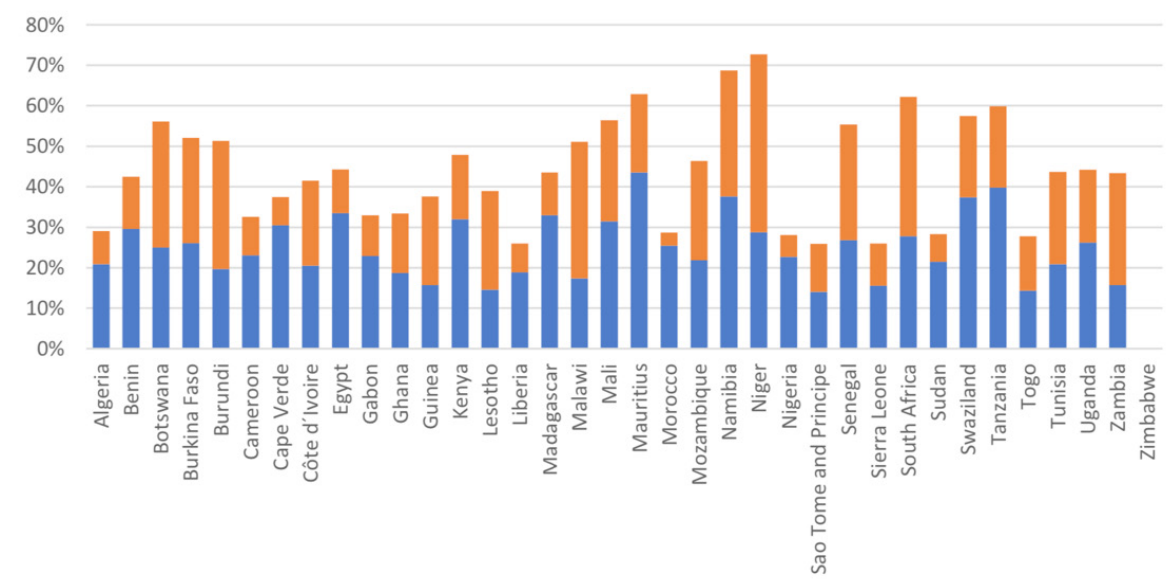

Figure 2. The Level of Trust on State's Tax Authority with a Low Level of Income (Source: Prichard et al., (2019) 
Besides, a strategy of improving obedience is related toa strategyon improving obedience through penalty and sanction that finally can affect obedience (Eek et al., 2002), and sometimes decreases obedience (Mulder et al., 2006). In terms of tax, several studies use trust as an indicator in improving tax compliance. The results of the studies have indicated that trust on government influences positively towards the level of tax compliance (Hunt et al., 2019), meanwhile, a trust on law and taxation has more effects on producing a level of obedience than giving sanction and penalty (Ratmono \& Cahyonowati, 2016).

From several previous studies, none of the studies discusses the communication aspect. Mostly, the previous studies merely focus on planning and strategy out of the context of communication. Therefore, this study aims to give a clear comprehension of how the logo 'rebranding' process of DGT carried out by DGT Public Relations in forming an image of the institute by displaying and presenting values of Indonesia Ministry of Finance as an organizational culture of DGT.

\section{LITERATURE REVIEW}

\section{The DGT Public Relations}

Public Relations (PR) is a management function that assists in forming and maintaining communication patterns, mutual understanding, income, and cooperation between a company and its public (community) (Cutlip et al., 2009). There are several points in Public Relations, namely: (1) issue and problem management; (2) assisting management to consistently obtain any information and being responsive on public opinion against his company organization; (3) assisting to define and convincing value of responsibility of the management to publics' necessity; (4) being considerate on any change and readiness to adopt with changes; and (5) using research techniques and ethical communication (Harlow, 1976; Theaker, 2001). Public Relations (PR) is a program that conducted and scheduled structurally to stimulate and progress the function of management as a media between organization and public - internally and externally. The PR aims to formulate and establish organization image to positively be reconsidered by the public's view (Azizah \& Imran, 2019).

According to The Ministry of Finance, in Article 552 Number 234/PMK.01/2015 on Organization and Rule of Orders at Ministry of Finance, the sub-directorate of Tax Public Relations is an echelon III unit that handles Public Relations in DGT. This unit positioned under of Directorate for Information, Service, and Public Relations (P2Humas) Directorate General of Taxes (Indonesia Ministry of Finance, 2015). On Article 561, the sub-directorate of Public Relations for Taxation has a duty in implementing investigation, policy-making, monitoring, controlling, and evaluation of technical policies implementation of Public Relations. Furthermore, in Article 562, the sub-directorate of Public Relations for Taxation conducts the following functions: 1) The preparation for analysis and operational-technical policies making of Public Relations; 2) Monitoring, controlling, and evaluating the technical and operational implementation of Public Relations; 3) Preparing program, implementing internal and external Public Relations, as well as monitoring and information management; and 4) Sites management.

Based on its organizational structure and Article 563, the Sub-directorate of Public Relations for Taxation consists of four segments/divisions (Indonesia Ministry of Finance, 2015). These four segments/divisions are Division for Internal Relation, Division for External Relations, Division for Sites Management, and Division for Information Management. Each division has its task. The Division for Internal Relation is to conduct internal Public Relations programs to the employees of DGT. The Division for External Relation conducts a program that relates to external relations, such as media and other parties. The Division for Site Management handles a site of the DGT and its official social media. At last, the Division for Information Management conducts monitoring on news and information that concerns taxes on some 
media.

\section{Planning and The Strategy of Public Relations}

In shaping an organization's image, Public Relations needs to establish and regulate the planning and strategy of communication. According to Kennedy \& Soemanagara (Bungin, 2015), there are three targets of changes in carrying out communication strategy, namely awareness change, attention, and loyalty. Sustainable communication strategies are a systematic and tactical way of identifying channels in terms of developing opinions and ideas and to attract the public's interest (Tatham, 2008). Therefore, informing an attitude, public treatment, and the public's trust, a strategy of communication is necessary to establish (Seyitoglu \& Yuzbasioglu, 2015). There are four significant points in implementing a communication strategy, namely: 1) Assessment; giving an illustration of the problem, 2) Communication and Analysis; mapping out the existing communication infrastructure, arranging communication objectives and indicator of evaluation, 3) Design; determining and stating a communication strategy, 4) Action; implementation and execution (Cangara, 2013).

\section{Logo Rebranding in Forming Identity and Image}

In projecting an organization visually, name (title) and logo are two popular elements (Poon, 1997). The visual identity illustration can increase the 'engagement' of consumers (Cian et al., 2014). The changing of identity can be successful as long as it can take and stimulate a positive attitude and behavior (Yalley, 2018). Corporate rebranding consists of fully rebranding and rebranding for the business unit (Muzellec \& Lambkin, 2006).

Rebranding is necessary because of changing market dynamics (Collange, 2015; Tevi \& Otubanjo, 2013). There are two factors that a company and organization implement rebranding, namely internal and external factors (Goi \& Goi, 2011). The significant change in the structure of the business organization is a part of the internal factors (Lomax et al., 2002).

According to (Jefkins, 2004), an image in Public Relations classified into five major parts, namely: 1) Mirror image; is an image where an institute or company has believed that the institute or company is in a pleasant atmosphere, and not to consider other people's impression; 2) Current image; is an image that condensed in publics and other parties about a company or institute; 3 ) Wish image; is an intended image by a company or institute; 4) Corporate image; is an image that emerges in an institute or company and covers the history and tracks of an institute or company -not only in its imagery of product, service, and capability of being socially responsible, but also a commitment in conducting any research, working principles, institute's successfulness, having wellestablished cooperation with stakeholders; and 5) Multiple images; is an image that previously emerges from some individuals, company branches, and representatives of some companies or institutes, but not the same as other institutes' images wholly.

\section{The Relationship between Organization Image and Public's Trust}

Trust in government frequently said as political trust (Anderson, 2010). Hetherington (1999) argues that the public's trust used to overview and evaluate how the government can operate by relying on the normative expectation of the public. In this case, Miller \& Listhaug (1998), argue that the normative expectation hold by the public against the government's working ability defined as the public's trust that is necessary to evaluate. Therefore, the public's trust is an essential factor in promoting wellestablished governance (Clark \& Lee, 2001).

Research by Kaur \& Soch (2018) found that image on a company emerges a strong determinant in terms of attitude loyalty, which is mediated by trust. Another research shows that the image of a company has a significant influence on trust ( $\mathrm{Lin} \& \mathrm{Lu}$, 2010). Richard \& Zhang (2012) conduct the 
same research by observing the impact of the company's image association against customer's loyalty in the travel industry. Their research has shown that the image of a company affects the satisfaction of customers significantly, and it can be implemented through trust and service giving.

\section{The Culture of Organization in the DGT}

The theory of cultural organization emphasizes the way a person can build a reality on a particular organization (Littlejohn \& Foss, 2011). The birth of cultural organizations in the broader context of culture has caused the cultural organization to become a complexity to define (Willcoxson \& Millet, 200o). Nevertheless, as quoted by Willcoxson \& Millet in previous relevant studies, it is defined as a result of all values on perception and attitude, as well as the identity of a group of people (Benedict, 1934; Kluckhohn \& Strodtbeck, 1961; Trice \& Beyer, 1993). The norms, principles, trust, and guidelines for behaving have become specific characteristics of the organization in defining cultural organization (Tambunan \& Anwar, 2019). Michael Pacanowsky and Nick O'Donnell-Trujillo (Morissan, 2009), the experts in the theory of cultural organization, suggest culture is not embedded and possessed by an organization, but culture is the organization itself. The idea of the theory of cultural organization by Pacanowsky \& Trujillo, next to be guided and developed by West \& Turner (2007) by suggesting three fundamental assumptions in the theory of cultural organization as follows: 1) The member of an organization creates and preserves a sense of solidarity and loyalty in the organization, and it can affect values in the organization. This assumption gives a strengthening idea on the existing values within the organization as a standard and principle of the organization; 2) The use and interpretation of a symbol have an essential role in the organization's culture. This assumption emphasizes on a symbol that involves verbal and nonverbal communication. A symbol can also communicate the organization's values; and 3) The existence of different cultures and conception in an organization. This assumption emphasizes the difference of culture and diversity of interpretations/ conceptions on each organization. This condition is associated with the construction of value and symbol on the organization.

Every organization or company has a culture of the organization. The value of an organization is a culture of the organization. In the context of Directorate General of Taxes, the embedded values as a culture of the organization are values of The Ministry of Finance. Those values are integrity, professionalism, synergy, service, and perfection. By these values, the employees of DGT, are expected to comprehend that working is a way to reach a vision; that is to be the best institute for the state's income in the interest of sovereignty and state's autonomy (Indonesia Ministry of Finance, 2019b).

\section{The Theory of Impression Management}

Erving Goffman introduces the concept of impression management since 1959 (Wang, 2016). In his book entitles "The Presentation of Self in Everyday Life", Goffman has indicated that the individual has his objective in reaching for the suitability between his image and the basic image for the expected objectives (Goffman, 1959). The theory of impression management takes a perspective on organization communication, and the relevant research conducted in mass communication, although the theory of impression management merely focuses on the interpersonal relationship (Arkin \& Shepperd, 1989; Dominick, 1999). The perspective of impression management is likely suitable to increase and improvise the understanding of the public's relationship because the theory and the public's relationship mostly involve the strategic control of information to communicate a particular impression for the audience (Benoit, 1995).

Based on underlying assumptions on the theory of organizational culture by West \& Turner (2007), one of these assumptions is about the symbol that exploited in communicating the values 
of the organization. According to Obasan (2012), organizational values that become a culture in organizations shape the image of the organization.

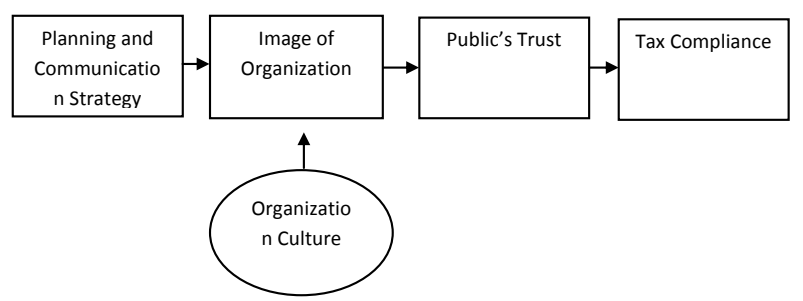

Figure 3. Theoretical and Conceptual Framework

\section{METHODS}

In this study, the technique of data collection was carried out by an interview. This interview was a primary tool to question a person on a particular theme and enables us to collect and his memory, idea, and experience (Porta, 2014). In determining an informant, this study used a purposive sampling technique; that was a technique to determine an informant based on particular consideration to obtain representative data (Sugiyono, 2012). In this study, the selected informant criteria were DGT public relations employees who were directly responsible and directly involved in each process of the DGT logo rebranding from beginning to end. Therefore, the sample who interviewed was chief of Internal Public Relations at Indonesia General Directorate of Taxes as the organizer coordinator of internal strategy making at DGT Public Relations. The questions within the interview arranged for the informant to give any information on the progressing processes during the logo rebranding by DGT.

The collection of data was done a year after the Decree of The Ministry of Finance (KMK) Number 865/KMK.03//2018 released on December 21, 2018. The technique of data collection using the sampleof data probability and non-probability. Thus, in this study, there was only the data of informant from a team of communication strategies at DGT Public Relations that selected, and there were none of the specific limitations in determining the amount of sample (Creswell \& Poth, 2016). As a triangulation to support and strengthen interview data, secondary data sources are also used by researchers. Interviews with other DGT internal communication strategy preparation team members were also conducted to strengthen the results of previous interviews. In strengthening the validity, other data also need to be added such as specific rules from the DGT and the Ministry of Finance related to the logo rebranding of the DGT.

The analysis of data was using the qualitative technique. According to Miles at al., (1994), there are some major points to carry out data analysis, namely: 1) data collection; 2) data condensation; 3) data display and; 4) findings and conclusion.

\section{RESULTS AND DISCUSSION}

Based on the result of the interview and triangulation of data, this study has found a finding that is analyzed by the ACADA model of communication planning. This model of communication planning consists of Assessment, Communication and Analysis, Design, and Action (Cangara, 2013).

\section{Assessment/Background of the Problem}

\subsection{Lack of trust against tax authorities}

The publics' perception of DGT is still negative. It is proven by the corruption mindset that has embedded for a long, and it creates a lack of trust against tax authorities.

"Indeed, the public still considered Directorate General of Taxes as identically to corruption, because we know that the reports on corruption by employees of the institute sufficiently highlighted at the time. So, it emerged publics' hesitance to trust Directorate General of Taxes" (Multhazam, the Chief of Internal Public Relations Division at DGT, December $5^{\text {th }}, 2019$ )

\subsection{Modern Communication that Has not been Supported by Logo}

Communication and service that are carried out by DGT have created a specific 'brand' that displayed in the modern, popular, and colorful form. However, it still has not been implemented and sensed not optimal in supporting an ideal pattern of 
communication.

\subsection{Have not possessed personal identity}

Since the establishment of DGT, this institute has not possessed personal identity as an image of its organization's culture, in contrast, the identity DGT refers to the identity of the Ministry of Finance of the Republic of Indonesia.

\subsection{Pre-unknown Values of the Ministry of Finance the Republic of Indonesia}

Presently, the public has not recognized the values of the Ministry of Finance as an organization's culture at the Directorate General of Taxes.

2. Communication and Analysis/Mapping out the existing communication infrastructure, the objective of communication, and the implementation of communication and evaluation indicators.

\subsection{The Official Units of DGT}

DGT has several official units that spread over Indonesia, and consists of 34 regional offices of DGT, 352 tax offices (KPP), and 204 Tax Service, Dissemination, and Consultation Offices ( $\left.\mathrm{KP}_{2} \mathrm{KP}\right)$. Every substance of communication that made and provided by DGT Public Relations, is next to be followed up to all units at regional offices of DGT. Each regional office of DGT delivers and reports to all Tax Offices (KPP) and all Tax Service, Dissemination, and Consultation Offices (KP2KP) as well as other offices under the control and management of the regional office of DGT.

\subsection{Public Relations Program at DGT}

DGT and all its units possess 11 Public Relations programs in the interest of communication and publication. The programs are 1) sympathetic campaign; 2) press conference; 3) the allocation of an information media kit (like leaflet, booklet, flyer, souvenir); 4) Helpdesk; 5) print media publication; 6) electronic media publication; 7) outside media publication; 8) online media publication; 9) Email blast; 10) direct socialization program, and 11) Internal
House Training (IHT). The eleven programs used in delivering material information and publication as well as the new logo of DGT.

\subsection{Objective of Communication}

The use and implementation of Public Relations programs in all units of DGT, has presented a new task logo that purposes of communicating the organization's image as a strong new-established identity of Indonesia Directorate General of Taxes.

\section{Design/The Decision of Strategy in Communication}

\subsection{The Use of Profesional Consultant}

In the strategy of image formulation, the DGT expects that the prospective image can give an accurate and correct impression. As necessary, the DGT invites a professional consultant who has an intensification of experience and knowledge on how the identity of the organization can be formed as proper to the objective of the organization. As to this, the Chief of Internal Public Relations Division at DGT, Multhazam said:

"So, the process of logo rebranding is a serious program. We want to change the negative mindset of the public. We want the public to trust in government, especially tax authority. We want the prospective image of the tax authority is relevant to what becomes our objective; that is the DGT which has a friendly image, responsible, dynamics, and serious"

\subsection{Phases in the Approach Planning by \\ Professional Consultant}

There are three phases in the approach planning that has been agreed and carried out by a professional consultant. These phases are:: 1) phase of research, 2) phase of logo branding development and 3) phase of branding implementation.

1.2.1 Phase of Research

In this phase, the consultant will analyze and evaluate the result of the previous surveys carried out by Public Relations of Tax intended to overview and take relevant data, 
such as information that relates to the identity of Directorate General of Taxes and its development. The consultant will also analyze the relevant information, such as the strategy of 'management change', vision and mission, and values to improvise so that the undertaken strategies can be formulated well.

3.2.2 Phase of Branding Strategy Development

The data resulted from research in the first phase formulated in the strategy of branding of DGT by developing Positioning Differentiation Brand (PDB). It proposed by DGT througha meeting (FGD) and workshop that consists of three main parts. First, finding exploration, such as determining market target, personification, brand values, and positioning). Second, brand strategy formulation (determining directions for logo, name (title), and 'tagline' of DGT). Third, brand strategy finalization (finalizing against all strategies that have been decided and agreed as a reference for development and translation to various collateral branding).

3.2.3 Phase of Branding Implementation This phase divided into two main parts, namely: the visual improvisation of corporate identity in various collaterals as well as the improvisation of service standard etiquette for the employees at DGT. In this phase, the application of the new logo merely used on Public Relations programs. Meanwhile, for the official programs like correspondence, and 'nametag' regularly refers to the previous regulation and decree of the Ministry of Finance.

The application of the new logo can also be seen in Table 1 . The elements within the new logo of tax have their meanings, either in their forms, kind of letters, and color.

Table 1. Meaning of the New Logo of DGT (Source: Indonesia Ministry of Finance, 2018)

Figure Clarification

1. The rectangular form symbolizes

1.1 A trustworthy institution.

1.2 Legal/formal regulation.

2. The more rounded form symbolizes:

2.1 Friendly.

2.2 Partnership.

3. The genre of the letter is 'sans serif'; it is supposed that it will sense modern, not rigid, and not consistently thin. These characteristics have a means of seriousness and having authority.

4. In the imaginary viewpoint, the two synergic elements can also be viewed as partner and friendship as if they have met, clasping one another, and greeting.

4.1 Form

4.1.1 The outside form is more and symbolize friendliness and flexibility more.

4.1.2 The deep square form symbolizes a distinct regulation.

4.1.3 Two identical forms represented by different colours symbolize justice that becomes the main principle of DGT.

4.1.4 The whole forms represent that the DGT is a friendly institute/organization

4.2 Colour

4.2.1 Two elements of colour represent a synergy between 'Subject to Tax and Tax autonomy; the blue one is for Indonesia Directorate General of Taxes, and the Yellow one is for 'Subject to Tax'. It indicates the importance of synergy between two parties to undertake a task on the state's income.

4.2.2 The two elements of a bright and dark light represent a task and function of DGT as a service institute and legal maintenance institute. 


\section{\begin{tabular}{ll}
\hline & Figure Clarification \\
\hline 4.2 .3 & The meanings of each kind of colour
\end{tabular} 4.2.3 The meanings of each kind of colour a. Gold; means prosperity; \\ b. Yellow; means a friendly partnership; \\ c. Blue; means professionalism; \\ d. Dark-Blue; means persistence.}

5. The brand colour of DGT takes two main colours, namely blue and yellow. The blue represents trust, professionalism, responsibility, and obligation. The yellow represents friendliness and values of good behaviour. The combination colour used is navy-blue and gold. The navy-blue represents persistence, and gold represents prosperity.

Table 1 addressed the application of values of the Ministry of Finance is seen as an organizational culture in DGT and used as a basis in the selection of elements within the new logo. As to integrate all elements within the values of the Ministry of Finance of the Republic of Indonesia as an organizational culture that involves integrity, professionalism, synergy, service, and perfection, a new logo has been declared by DGT through Decree Number 865/ KMK.03/2018 on December 21, 2018. This achievement is expected that the formulation of the image as a new identity reflection of DGT can correctly implicate to the high intensity of tax compliance.

\section{Action/Implementation}

\subsection{The Decision of Regulation/Specific Policy}

It is to declare the results through specific policy signed and approved by the General Director of Taxation and the Ministry of Finance of the Republic of Indonesia. This term of the condition seems to be engaged to allvertical unitsat taxation offices in Indonesia and can be undertaken simultaneously by the units of DGT. Besides, it becomes a guideline in the usage and application of the new logo in DGT to avoid deviation in its application and implementation.

"all processes will not make a sense as not applied by the official unit of taxation and its employee in various activities. Therefore, we decide to use the new logo that approved and signed by the General Director of Taxation. This way carried out so that the use and application (implementation) of the new taxation logo is relevant to our hopes and objective" (Arif, Staff of Internal Public Relations Division at DGT, December $5^{\text {th }}, 2019$ ).

\subsection{Undertaking a Monitoring}

Some of the informants argue that the programs undertaken by the professional consultant and internal official of DGT should always be monitored to take it into efficient and effective progress.

The following table is the summary of the planning analysis of DGT by using the ACADA communication planning model (See Table 2).

Table 2. Model of Planning Rebranding logo of the DGT

Assessment
1. Lack of trust against the tax authority
2. Modern Communication that has not been
accommodated by the logo
3. Have not possessed a private identity
4. Have not recognized values of the Ministry
of Finance of The Republic of Indonesia
1. Communication and Analysis
2. Public Relations' Program of the DGT
3. Objective of Communication
1. The Presence of a Professional Consultant
2. The Phase of Planning Approach
2.1 Phase of Research
2.2 Phase of Branding Strategy Development
2.3 Phase of Branding Implementation
The Decision of Specific Rule

\section{Discussion}

The result of this study indicates that a process of logo rebranding in an institution is a sophisticated program that takes a long time for completion. Public Relations should 
formulate the expected target as well as possible (Nguru \& Ibrahim, 2018). Therefore, it is necessary to conduct a profound study like a survey on the public's perception and satisfaction. From the result, the corruption mindset that causes a lack of trust against tax authority is one of the crucial problems to be responded to and undertaken by the DGT Public Relations. The low level of public trust affects the image of an institution, and it is the first stage to undertake logo rebranding that has become part of Corporate Visual identity. In terms of better institution's image formulation, any change on elements within Corporate Visual identity should take into concern (Bolhuis et al., 2015).

The Brand created through the communication of the taxation employees is a positive thing. The reason is that the corporate image is an image that emerges and involves the elements within the organization (Jefkins, 2004) and that the tax authority has a negative corporate image. In supporting the brand of friendly communication, it is necessary to link it with a logo to create continuity.

The Corporate image formed as the identity that still refers to the Ministry of Finance is still embedded and adhered since the establishment of DGT. DGT, as an institution with a crucial role in a state, should be able to gain trust in the public. According to Clark \& Lee (2001), in promoting good governance, the publics' trust is necessary. Therefore, the DGT needs to have a private identity in forming a better image as an institution with its important role in the state's income.

In the interest of the established mutual relationshipbetween the public and the needs of an organization, Public Relations should be able to form values, comprehension, attitude, and behavior (Sumarto, 2016). The values professed by the DGT are the values of the Ministry of Finance that involve integrity, professionalism, synergy, service, and perfection. However, these values have not recognized by the public. In the theory of organizational culture, West \& Turner (2007) affirm that values and symbols are the matters that need to intensify because symbols can communicate values on the organization. It means that values in organizations have become crucial to communicate the public in forming a better image of the organization. The values of the DGT as an organizational culture as explained in the organizational culture theory above must be communicated to the public. One of these communications is through the logo as an organizational symbol used in shaping the image of the organization.

In the process of logo rebranding logo refers to the decision of objective and the selection of communication channel. The DGT has some communication channels, like social media as it becomes a program of Public Relations that can be exploited in the publication of a logo. Besides, the unit and employee as the agent of communication that spread over Indonesia, should participate in communicating the new logo of DGT.

The presence of the professional consultant is an important strategy of DGT Public Relations in forming a better image of the institute. The selection of the professional consultant is undertaken through a long process to produce the best and professional consultant in accommodating the need for DGT. In the strategy of image forming, the DGT expects that the prospective image will deliver a proper and correct impression based on experience, knowledge, and comprehension against a factual reality (Anggoro, 2000).

The steps undertaken by a professional consultant was started by profound research up to the implementation of branding itself. Therefore, DGT Public Relations should conduct a guardianship and monitoring against all programs within the process of logo rebranding; this way undertook to reach the target and objective of the organization. Besides, it is to anticipate and minimizing possible problems within the process of forming a positive image. It means that Public Relations will face a variety of problems and barriers (Khopipah \& Turistiati, 2019).

The step for implementation and monitoring against the internal aspect 
is complex. Moreover, the DGT is a big organization whose units spread along with Indonesia. Therefore, to undertake a project, the DGT Public Relations will conduct internal socialization concerns particular rule on the application and implementation of branding that is used appropriately by the tax office's units as not to decrease or even add other elements within the new logo.

\section{CONCLUSION}

The logo rebranding undertaken by the DGT purposes to be able to form an image that is previously identical with corruption mindset, awkward, and not friendly to be a better image that characterizes friendly, responsible, professional, dynamics, and severe. The process of logo rebranding carried out by the DGT, has addressed an idea that in doing logo rebranding on the organization to form better corporate image, there needs to be summarized through ACADA strategy and planning model that involves some steps, namely: 1) Assessment; 2) Communication and Analysis; 3) Design; and 4) Action. This study has an academic and practical implication. From an academic viewpoint, especially for future research, this study expected to overview and observe the response and perception of the public against logo rebranding by the DGT to view the influence of the logo rebranding. In its practical significance, this study expected to give a reflection and knowledge on organization or institute, particularly governmental institutes in undertaking logo rebranding.

\section{ACKNOWLEDGEMENT}

The researchers would like to thank in advance for the Editor in Chief, Benni Setiawan, the Editor Ni Made Ras Amanda $G$ and the reviewer (anonymous) for valuable commentaries and suggestions for this research.

\section{REFERENCES}

Anderson, M. R. (2010). Community psychology, political efficacy, and trust. Political Psychology, 31(1), 59-84. Doi: 10.1111/j.1467-9221.2009.00734.X
Anggoro, M. L. (200o). Teori \& profesi kehumasan serta aplikasinya di Indonesia. Bumi Aksara.

Arkin, R.M., Shepperd, J. A. (1989). Selfpresentation styles in organizations. In P. Giacalone, Robert A., Rosenfeld (Ed.), Impression management in the organization (pp. 125-139). New Jersey: Lawrence Erlbaum Associates, Inc.

Azizah, N. Z. N., \& Imran, A. I. (2019). Proses PublicRelationsPT.KeretaApiIndonesia (Persero) dalam Membangun Citra Positif melalui Media Sosial Instagram @Keretaapikita. Performance: : Jurnal Personalia, Finansial Operasional, Marketing Dan Sistem Informasi, 26(1), 19-26. Doi: 10.20884/1.jp.2019.26.1.1385

Benedict, R. (1934). Patterns of culture. Boston; New York: Houghton Mifflin Company.

Benoit, W. L. (1995). Account, Excuses, and Apologies: A Theory of Image Restoration Strategies. Albany: State University of New York Press.

Bolhuis, W., De Jong, M. D. T., \& Van den Bosch, A. L. M. (2015). Corporate rebranding: effects of corporate visual identity changes on employees and consumers. Journal of Marketing Communications, 24(1), 3-16. Doi: 10.1080/13527266.2015.1067244

Bungin, B. (2015). Pemasaran dan Brand Destinasi. Jakarta: Kencana.

Cangara, H. (2013). Perencanaan dan Strategi Komunikasi. Jakarta: PT. Raja Grafindo Aksara.

Cian, L., Krishna, A., \& Elder, R. S. (2014). This Logo Moves Me: Dynamic Imagery from Static Images. Journal of Marketing Research, 51(2), 184-197. Doi: 10.1509/ jmr.13.0023

Clark, J.R., \& Lee, D. R. (2001). The optimal trust in government. Eastern Economic Journal, 27(1), 19-34. Retrieved from https://www.jstor.org/stable/40326012

Collange, V. (2015). Consumer reaction to 
service rebranding. Journal of Retailing and Consumer Services, 22, 178-186. Doi: 10.1016/j.jretconser.2014.07.003

Creswell, J. W., \& Poth, C. N. (2016). Qualitative inquiry and research design: Choosing among five approaches. Sage Publications.

Cutlip, S.M., Center, A.H., \& Broom, G. M. (2009). Effective Public Relations (9th ed.). Jakarta: Kencana.

Detik Finance. (2018, September 16). Tingkat Kepatuhan Pajak Masyarakat RI Masih Rendah. Retrieved from https:// finance.detik.com/berita-ekonomibisnis/d-4214299/tingkat-kepatuhanpajak-masyarakat-ri-masih-rendah

Dominick, J. R. (1999). Who Do You Think You Are? Personal Home Pages and SelfPresentation on the World Wide Web. Journalism \& Mass Communication Quarterly, 76(4), 646-658. Doi: 10.1177/107769909907600403

Eek, D., Loukopoulos, P., Fujii, S., \& Garling, T. (2002). Spill-over effects of intermittent costs for defection in social dilemmas. European Journal of Social Psychology, 32(6), 801-813. Doi: 10.1002/ejsp.122

Fajri, C. (2017). Peran Humas Dalam Meningkatkan Loyalitas Stakeholders Universitas Ahmad Dahlan. Informasi, 47(1), 97-108. Doi: 10.21831/informasi. v47i1.14885

Goffman, E. (1959). The Presentation of Self in Everyday Life. New York: Doubleday.

Goi, C. L., \& Goi, M. T. (2011). Review on models and reasons of rebranding. International Conference on Social Science and Humanity, 5(2), 445-449. Retrieved from http://www.ipedr.com/ vol5/no2/99-H10243.pdf

Harlow, R. F. (1976). Building a public relations definition. Public Relations Review, 2(4), 34-42. Doi: 10.1016/So3638111(76)80022-7

Hetherington, M. J. (1999). The effect of political trust on the presidential vote, 1968-96. American Political Science Review, 94(2), 311-326. Doi: $10.2307 / 2585398$

Hunt, N. C., Iyer, G. S., \& Jimenez, P. (2019). Election Outcome and Tax Compliance: The Role of Political Party Affiliation, Affect Balance, and Trust in Government. Applied Psychology, 68(2), 341-372. Doi: 10.1111/apps.12165

Indonesia Ministry of Finance. (2015). Peraturan Menteri Keuangan Nomor 234/PMK.o1/2015 tanggal 20 November 2015 Tentang Organisasi dan Tata Kerja Kementeriangan Keuangan. Jakarta: System for Documentation and Legal Information (JDIH) Indonesia Ministry of Finance.

Indonesia Ministry of Finance. (2018). Keputusan Menteri Keuangan Nomor 865/KMK.o3/2018 Tanggal 21 Desember 2018 Tentang Logo Direktorat Jenderal Pajak. Jakarta: Indonesia Ministry of Finance.

Indonesia Ministry of Finance. (2019a). APBN 2019. Retrieved from https:// www.kemenkeu.go.id/apbn2019

Indonesia Ministry of Finance. (2019b). NilaiNilai Kementerian Keuangan. Retrieved from https://www.kemenkeu.go.id/ profil/nilai-nilai-kementeriankeuangan

Jefkins, F. (2004). Public Relations. Jakarta: PT. Gelors Aksara Pertama Erlangga.

Kaur, H., \& Soch, H. (2018). Satisfaction, Trust and Loyalty: Investigating the Mediating Effects of Commitment, Switching Costs and Corporate Image. Journal of Asia Business Studies, 12(4), 361-38o. Doi: 10.1108/JABS-08-2015-0119

Khopipah, S., \& Turistiati, A. T. (2019). Challenges of dual roles of marketing public relations and public relations in developing a positive image of PT. Overseas Zone. Informasi, 49(2), 91-100. Doi: 10.21831/informasi.v49i2.28256

Kim, S. (2010). Public trust in government in Japan and South Korea: Does the 
rise of critical citizens matter? Public Administration Review, 70(5), 801-810. Doi: 10.1111/j.1540-6210.2010.02207.x

Kirchler, E., Hoelzl, E., \& Wahl, I. (2008). Enforced versus voluntary tax compliance: The "slippery slope" framework. Journal of Economic Psychology, 29, 210-225. Doi: 10.1016/j. joep.2007.05.004

Kluckhohn, F. R., \& Strodtbeck, F. L. (1961). Variations in value orientations. Evanston, Illinois: Row, Peterson.

Kotler, P., \& Keller, K. L. (2009). Manajemen Pemasaran, Edisi 13. Jakarta: Erlangga, 14.

Lin, L.Y., \& Lu, C. Y. (2010). The influence of corporate image, relationship marketing, and trust on purchase intention: the moderating effects of word-of-mouth. Tourism Review, 65(3), 16-34. Doi: 10.1108/16605371011083503

Littlejohn, S.W., \& Foss, K. A. (2011). Theoris of Human Communication (1oth ed.). America: Waveland Press, Inc.

Lomax, W., Mador, M., \& Fitzhenry, A. (2002). Corporate Rebranding: Learning from Experience. UK: Kingston Business School.

Lund, D. B. (2003). Organizational Culture and Job Satisfaction. Journal of Business E Industrial Marketing, 18(3), 219-236. Doi: 10.1108/0885862031047313

Melewar, T. C., \& Saunders, J. (1998). Global corporate visual identity systems: standardization, control and benefits. International Marketing Review, 15(4), 291-308. Doi: 10.1108/02651339810227560

Melewar, T.C., Gotsi, M. and Andriopoulos, C. (2012). Shaping the research agenda for corporate branding: avenues for future research. European Journal of Marketinging, 46, 600-6o8. Doi: 10.1108/03090561211235138

Miles, M. B., Huberman, A. M., Huberman, M. A., \& Huberman, M. (1994).
Qualitative data analysis: An expanded sourcebook. Sage.

Miller, A.H., \& Listhaug, O. (1998). Policy preferences and political distrust: A comparison of Norway, Sweden and the United States. Scandinavian Political Studies, 21(2), 161-187. Doi: 10.1111/ j.1467-9477.1998.tbooo10.x

Miller, D., Merrilees, B., \& Yakimova, R. (2014). Corporate Rebranding: An Integrative Review of Major Enablers and Barriers to the Rebranding Process. International Journal of Management Reviews, 16(3), 265-289. Doi: 10.1111/ ijmr.12020

Morissan. (2009). Teori Komunikasi Organisasi. Jakarta: Global Indonesia.

Mulder, L. B., Van Dijk, E., De Cremer, D., \& Wilke, H. A. M. (2006). Undermining trust and cooperation: The paradox of sanctioning systems in social dilemmas. Journal of Experimental Social Psychology, 42(2), 147-162. Doi: 10.1016/j.jesp.2005.03.002

Muzellec, L., \& Lambkin, M. (2006). Corporate rebranding: Destroying, transferring or creating brand equity? European Journal of Marketing, 40(7/8), 803-824. Doi: 10.1108/03090560610670007

Nguru, M. N., \& Ibrahim, A. M. (2018). Public Relations and Employee Performance in Nigerian Institutions of Higher Learning. Informasi, 48(2), 267-279. Doi: 10.21831/informasi.v48i2.21972

Obasan, K. A. (2012). Organisational culture and its corporate image: A model juxtaposition. Business and Management Research, 1(1), 121-132. Doi: 10.5430/bmr.vinip121

OECD. (2019). Global Revenue Statistics Database. Retrieved from https:// www.oecd.org/tax/tax-policy/globalrevenue-statistics-database.htm

Poon, J. P. T. (1997). Communicating a Winning Image. Industrial and Commercial Training, 29(5), 158-165. Doi: 10.1108/o0197859710171770 
Porta, D. D. (2014). Methodological practices in social movement research. OUP Oxford.

Prichard, W., Custers, A., Dom, R., Davenport, S., \& Roscitt, M. (2019). Innovations in Tax Compliance: Conceptual Framework.

Ratmono, D., \& Cahyonowati, N. (2016). Kepercayaan Terhadap Otoritas Pajak Sebagai Pemoderasi Pengaruh Deterrence Factors Terhadap Kepatuhan Wajib Pajak Pribadi. Jurnal Akuntansi Indonesia, 2(1), 1-15. Doi: 10.30659/jai.2.1.1-15

Richard, J.E., \& Zhang, A. (2012). Corporate image, loyalty, and commitment in the consumer travel industry. Journal of Marketing Management, 28(5-6), 568593. Doi: 10.1080/0267257X.2010.549195

Ruslan, R. (1999). Manajemen Humas dan Manajemen Komunikasi (Konsepsi dan Aplikasi). Jakarta: PT Raja Grafika Persada.

Seyitoglu, F., \& Yuzbasioglu, N. (2015). The role of strategic communication in hospitality industry. The Case of Antalya, 2(2), 16-35. Doi: 10.5296/jsss. v2i2.6526

Sonenshein, S. (2010). We're changingOr are we? Untangling the role of progressive, regressive, and stability narratives during strategic change implementation. Academy of Management Journal, 53(3), 477-512. Doi: 10.5465/amj.2010.51467638

Sugiyono. (2012). Metode Penelitian Kuantitatif, Kualitatif, dan RED. Bandung: Alfabeta.

Sumarto, R. H. (2016). Komunikasi dalam Kegiatan Public Relations. Informasi, 46(1), 63-72. Doi: 10.21831/informasi. v46i1.9650

Sutojo, S. (2004). Membangun Citra Perusahaan. Jakarta: Damar Mulia Pustaka.
Tambunan, M. R., \& Anwar, R. (2019). Transformasi Budaya Organisasi Otoritas Perpajakan Indonesia Menghadapi Era Ekonomi Digital. Jurnal Aplikasi Bisnis Dan Manajemen (JABM), 5(2), 252. Doi: 10.17358/ jabm.5.2.253

Tatham, S. (2008). Strategic communication: a primer. Shrivenham: Defence Academy of the United Kingdom.

Tevi, A.C., \& Otubanjo, O. (2013). Understanding corporate rebranding: An evolution theory perspective. International Journal of Marketing Studies, 5(3), 87-93. Doi: 10.2139/ ssrn.2197664

Theaker, A. (2001). The Public Relations Handbook. London: Routledge.

Torgler, B. (2007). Tax compliance and tax morale: A theoretical and empirical analysis. MA: Edward Elgar Publishing, Inc.

Trice, H. M., \& Beyer, J. M. (1993). The cultures of work organizations. Englewood Cliffs: Prentice-Hall, Inc.

Vallaster, C. and Lindgreen, A. (2011). Corporate brand strategy formation: Brand actors and the situational context for a business-to-business brand. Industrial Marketing Management, 40(7), 1133-1143. Doi: 10.1016/j. indmarman.2011.09.008

Van den Bosch, A. L., De Jong, M. D., \& Elving, W. J. (2005). How corporate visual identity supports reputation. Corporate Communications: An International Journal, 10(2), 108-116. Doi: 10.1108/13563280510596925

Wang, J. L. (2016). Literature Review on the Impression Management in Corporate Information Disclosure. Modern Economy, 7(6), 725-731. Doi: 10.4236/ me.2016.76076

West, R., \& Turner, L. H. (2007). Pengantar Teori Komunikasi. Jakarta: Salemba Humanika. 
Willcoxson, L., \& Millet, B. (2000). The management of organization culture. Australian Journal of Management and Organization Behaviour, 3(2), 91-99. Retrieved from http://eprints.usq.edu. $\mathrm{au} / \mathrm{id} / \mathrm{eprint} / \mathbf{1 4 0 3 7}$

$\mathrm{Wu}$, H. C. (2014). The effects of customer satisfaction, perceived value, corporate image and service quality on behavioral intentions in gaming establishments. Asia Pacific Journal of Marketing and Logistics, 26(4), 540-565. Doi: 10.1108/ APJML-03-2014-0049

Yalley, A. A. (2018). Voter Response to Logo Rebranding of Electoral Management Bodies in Young Democracies: The Rebranding of the Electoral Commission of Ghana. Journal of Political Marketing, 1-23. Doi: 10.108o/15377857.2018.1477692 